\title{
CODE-SWITCHING AS MEDIA SPEECH: AN EVIDENCE IN INDONESIAN PODCAST
}

\author{
Fathia Anggriani Pradina \\ Universitas Trilogi, Jakarta, Indonesia \\ Email: fathia.pradina@trilogi.ac.id
}

\author{
Article history: \\ Submitted Oct 05, 2020 \\ Revised Nov 18, 2020 \\ Accepted April 13, 2021 \\ Published June 11, 2021
}

\begin{abstract}
A communicative code plays a main role in every conversation. The aim is to make a communicative goal in every situation. In this digital era, people tend to make something interesting to attract people's attention. Namely Podcast, is one of the programs in digital platform that been used as the media to share everything in audio output. In Podcast, the host uses code-switching to make the communication livelier and sometimes to emphasize the statements or questions. Therefore, the host and the guest will have a very communicative interaction along the interview. This study aims to analysed the situational goal in a Podcast which host uses English as his switching code. The situational goal can be seen from the type of code-switching that the host used connected to the type of illocutionary forces at the speech act level. The data are recorded and transcribed from several episodes of the Podcast. The result shows that code-switching as the media speech is deliberately use as a very functional code to reach the situational goal.
\end{abstract}

Keywords: code-switching; digital media; Indonesia; podcast

\begin{abstract}
ABSTRAK
Kode komunikatif memainkan peran utama dalam setiap percakapan. Tujuannya adalah untuk membuat tujuan komunikatif dalam setiap situasi. Di era digital ini, orang cenderung membuat sesuatu yang menarik untuk mendapatkan perhatian orang. Podcast, adalah salah satu program dalam platform digital yang telah digunakan sebagai media untuk berbagi dalam output audio. Di Podcast, pembawa acara menggunakan alih kode untuk membuat komunikasi menjadi lebih hidup dan terkadang untuk menekankan pernyataan atau pertanyaan. Oleh karena itu, pembawa acara dan tamu akan memiliki interaksi yang sangat komunikatif sepanjang wawancara. Penelitian ini bertujuan untuk menganalisis tujuan situasional dalam Podcast pada saat pembawa acara menggunakan bahasa Inggris sebagai alih kode. Tujuan situasional dapat dilihat dari jenis alih kode yang digunakan tuan rumah terhubung ke jenis ilokusi pada tingkat tindak tutur. Data direkam dan ditranskripsi dari beberapa episode Podcast. Hasilnya menunjukkan bahwa alih kode berfungsi sebagai media bahasa,
\end{abstract}


Fathia Anggriani Pradina - Code-Switching as Media Speech: An Evidence in Indonesian Podcast

sengaja digunakan sebagai kode yang sangat fungsional untuk mencapai tujuan situasional.

Kata kunci : alih-kode; media digital; Indonesia; podcast

\section{INTRODUCTION}

Basically, Indonesian people can speak more than one languages since they childhood because each Indonesian was born into individual of different cultures and each culture has its own language. That makes the people in Indonesia are bilingual by nature. They can speak the national language, that is Indonesian, and also their own local language. This situation leads Indonesian people to learn another foreign language one of which is English. The use of English in Indonesia develops rapidly. Not only it becomes one of the foreign language subjects at school, but also language use of everyday life through conversation.

The use of English language can be seen in the social media. In Indonesia, one of social media that has been used widely right now is Podcast. Podcast is an episodic series of spoken word digital audio files that listener can use through their gadget. It becomes an easy way to share information from a casual interview. The topics can be varied, but the most interesting topic concern daily life activities. Podcast is conducted by the host to run the interview and bring the topic alive.

In this event, the host must be the one who holds the ability to use language properly to make the interview runs smoothly. By the proper language use, the aim of the interview will be reached. The guest can understand every utterance and question correctly, so the interview becomes livelier. Thus, all of that will lead to the listeners. They do not have to think really hard to understand the conversation. Additionally, the listeners will enjoy listening to the program. By switching the codes, the host is not only helping himself but also, the listeners to understand.

One of the strategies that can be done by the host is switching his language from the base language to the target language or we can call it codeswitching. Code switching is often used in conversation. Now, it has become a 
normal situation if the host in Podcast switching his language from one to another. In addition to showing the ability of his language, switching a language also helps the host to express what he wants to say easily. To create a common sense, the host should have the ability to make the conversation runs communicatively. Switching codes is one of the ways to reach the goal. A good conversation can be seen from the language used. Language or so-called code in Sociolinguistics is one of the tools that has main role in every conversation. Through the proper use of codes, it shows that the host uses communicative code. A communicative code would be a way of transduction between intentions and utterances, also between utterances and interpretations. Thus, "the speaker and listener may have a switching of communicative code with language alternation, not-switching with language alternation, not-switching without language alternation or switching of codes without language alternation" (Auer, 1998).

As the result of language used, changing code also can be said as codeswitching. According to Hornbeger \& McKay (2010), code-switching occurs if there are two or more languages used and happened frequently from the speaker. Holmes (2001) also said that code-switching also can be motivated by the participant. Code-switching often occurs if the speakers have the ability to speak more than one language and they use the languages at the same time in the same context. Means, the speakers do not have intention to change the meaning of the utterance, while it is used to emphasize the purpose. The term code-switching used interchangeably with code-mixing. Some of the researches agree that code-switching and code-mixing are different, but some not. Holmes (2001) said that code-switching and code-mixing are the same. People who has the ability to speak more than one languages or bilingual use code-switching in their utterance. Code-switching is potentially the result from the bilingual speaker when they are not capable to use the languages properly or even put in a separate way. On the other hand, as Hoffman (1991) said that bilingual people tend to use the languages in their conversation whether it is to make the message of the utterance clearer or even they don't know the right way to use it 
Fathia Anggriani Pradina - Code-Switching as Media Speech: An Evidence in Indonesian Podcast

separately. Hoffman (1991) also explains several reasons why bilingual people switch or mix their languages are because they are talking about particular topic, expressing someone else's quotes, being emphatic about something, inserting sentence connectors or interjection, clarification, or clarifying the speech content for interlocutor and expressing group entity.

There are several types of code-switching regarding to Edwards (1994): (1). Tag-switching. This type shows that the switching of the code occurs at the end of the sentence or utterance. The speakers switch the code into a question tag by using different language from the first sentence. This type of switching can be said as mixing according to Edwards (1994). Tag-switching can occur in both interrogatory or exclamatory. (2). Intrasentential switching. This type of switching occurs in the middle of a sentence or utterance. The speakers usually insert a word, mainly lexical item, to emphasize the utterance. Sometimes the switching is better seen as the repeated switching from the previous word or lexical item. It is simply to make the utterance clear in both languages. (3). Intersentential switching. This type of switching can occur in the beginning or in the end of the sentence or utterance, but not in the middle. This makes intersentential switching is different from intrasentential switching. Another difference is that in intersentential switching, the switching occurs in a clause or sentence boundary.

Research in code-switching related with social media has been done by some fellow researchers. Some of the researchers are Yuliana, N., Luziana, A. R., Sarwendah, P (2015) conducted a research about code-mixing and codeswitching of Indonesian Celebrities. Lubis, S.I., Surya, S., Muka, S.U (2017) did the research about the use of code-switching among adolescent in Facebook. Kristanto, J., Meilasari, P (2018) studied the use of code-switching in social media's users in the Indonesian teenagers. Most of researches only analyze about the type of code-switching or code-mixing that being used and connect it to its function. 
In this study, the writer tries to analyze the use of code-switching as the media speech communicated by the host in emphasizing his statements or questions to the guest. Analyzing the type of code-switching and connect the classes of illocutionary acts to find the evidence that the host is trying to obtain the communicative purposes by performing illocutionary force. As illocutionary force is one of the instruments in code-switching to get the speaker's communicative purposes to the listener. Thus, this study not only used Sociolinguistics approach, but also undertaken through Pragmatics approach to analyze the speech.

\section{THEORY AND METHOD}

The code-switching can be linked to other theories because language is not only in one subject of linguistics. In this study, according to Auer (1998) codeswitching can reach the communicative purposes connected to the illocutionary forces at speech act level. Illocutionary forces could be performed from the certain illocutionary acts. The illocutionary acts were introduced by Austin in his book "How to do Things with Words", he explained that illocutionary acts are the act of performative and constative utterances that make result in doing something or act. Searle (1976) in her book "Language in Society" explains that there are five classes in illocutionary acts, (1). Assertive that commit a speaker to the truth of the expressed proposition, (2). Directives that cause the hearer to take a particular action, e.g. requests, commands and advice, (3). Commissive that commit a speaker to some future action, e.g. promises and oaths, (4). Expressive that express on the speaker's attitudes and emotions towards the proposition, e.g. congratulations, excuses and thanks, (5). Declarations that change the reality in accord with the proposition of the declaration, e.g. baptisms, pronouncing someone guilty or pronouncing someone husband and wife. The connection between code-switching and illocutionary acts to reach the situational goal can be seen from the table below: 
Fathia Anggriani Pradina - Code-Switching as Media Speech: An Evidence in Indonesian Podcast

\begin{tabular}{|c|c|c|c|c|c|c|c|c|c|c|c|}
\hline \multicolumn{12}{|c|}{ SG } \\
\hline \multicolumn{12}{|c|}{$\mathrm{SC}$} \\
\hline \multicolumn{2}{|c|}{ EG1 } & \multicolumn{4}{|c|}{ EG2 } & \multicolumn{3}{|c|}{ EG3 } & \multicolumn{3}{|c|}{ EG4 } \\
\hline \multicolumn{2}{|c|}{ EC1 } & \multicolumn{4}{|c|}{ EC2 } & \multicolumn{3}{|c|}{ EC3 } & \multicolumn{3}{|c|}{ EC4 } \\
\hline SA1 & SA2 & SA3 & SA4 & SA5 & SA6 & SA7 & SA8 & SA9 & SA10 & SA11 & $\mathrm{SA} 12$ \\
\hline $\mathrm{SC} 1$ & $\mathrm{SC} 2$ & $\mathrm{SC} 3$ & SC4 & SC5 & SC6 & SC7 & SC8 & SC9 & $\mathrm{SC} 10$ & SC11 & $\mathrm{SC} 12$ \\
\hline A & B & A & B & B & & & \begin{tabular}{l|l} 
A & $A$
\end{tabular} & A & A & B & A \\
\hline
\end{tabular}

SG, situational goal; SC, situational code; EG, episode or activity goal; EC, episode or activity code; SA, speech act; SC, speech-act code; A, B, utterances in alternating varieties

The table above is taken from Auer (1998), it explains that to reach the situational goal, speech act has an important role in the utterance. Speech act leads to the activity code then goes to activity goal results in the situational goal. Every utterance is the result of the interaction of various code done at several level. It means that, code-switching done by the speaker has its speech act level meaning in every utterance since codes are directly connected to communicative goals. Therefore, every code-switching from the speaker may have meaning even though not all need to. Switching code can affect to the various level of meaning. Auer (1998) also said "...many cases of what is known as fluent 'conversational code-switching' (whether 'intrasentential' or 'intersentential') can be envisioned, at the structural level, as an alloy of two or more speech varieties, which signals a number of situational and local intentions through a number of codes." Conversational code-switching is not only merely occurring because the speaker wants to use different codes, but also it has another function, which is to build the situational goal.

This study uses descriptive qualitative method by taking some interviews into account about personal experiences, life story, dreams, and anything that related with the topic during the interview. The linguistic form of codeswitching is linked with the illocutionary act to examine the use of codeswitching in the interview as the speech to get the situational goal. 
Fathia Anggriani Pradina - Code-Switching as Media Speech: An Evidence in Indonesian Podcast

The data were taken from several episodes of a podcast channel in Indonesia which the host is using Indonesian and English as his speech to conduct the interview. The data were recorded and transcribed. There are some following steps in collecting the data, (1). The writer determines the podcast channel that use code-switching from Indonesian to English more often. (2). The writer determines the episodes that relate with the common topic so it can have relation with daily life issues. (3) The writer records and transcribes the interview from two episodes.

In this research, the data shows the type of code switching from Edwards (1994) and illocutionary act from Austin (1975) match the analysis. Along the process, there were some data that did not link with the theories. Therefore, the data were omitted. It was the process of data reduction. Meanwhile, the data that were matched with the theories are explained in the discussion.

\section{FINDING AND DISCUSSION}

The focus of this research is the communicative purposes of the host during the interview. The interview is taken form two episodes, episodes 82 and 94, from the same podcast channel with the same host. In episode 82, the host was interviewing an Indonesian content creator about things that related with her job, appearance, life story, marriage and the issue that she brings about mental health. The interview was 38 minutes long, conducted in Indonesian and English. While in episode 94, the host was interviewing an Indonesian actor. The interview was about the activity of the actor during the covid-19 lockdown in Indonesia, educational story, passion towards his profession and his admiration to his mother. A 48-minutes interview was conducted in Indonesian and English.

The table below is the findings of the code-switching and the illocutionary acts that appear from the host during the interview. It can be seen that the types of codeswitching appear in the utterance are intrasentential switching, intersentential switching and tag-switching. While the illocutionary acts appear are assertive, directive, and expressive. Commissive and declaration did not find in the corpus. 
Fathia Anggriani Pradina - Code-Switching as Media Speech: An Evidence in Indonesian Podcast

Tabel 1. Result finding of code-switching and illocutionary acts

\begin{tabular}{cccccc}
\hline $\begin{array}{c}\text { Code- } \\
\text { switching }\end{array}$ & Assertive & Directive & Commissive & Expressive & Declaration \\
(CS) & 18 & 12 & 0 & 5 & 0 \\
\hline Intersentential & 6 & 1 & 0 & 3 & 0 \\
Intrasentential & 2 & 6 & 0 & 1 & 0 \\
Tag & 2 & &
\end{tabular}

The table explains the componential analysis of the findings, that intersentential switching $64,81 \%$ appears as the most frequent, followed with intrasentential switching $18,51 \%$ and the last is tag-switching $16,66 \%$. It also affects to the types of illocutionary acts that link with the code-switching. Assertive is the most frequent $48,14 \%$, directive $35,18 \%$, expressive $16,66 \%$ while commissive and declaration did not find in the interview.

From the three types of code-switching regarding to Edwards (1994) in this study, it can be seen that intersentential switching appears to be the most frequent. The host switches his language either it is in the beginning or at the end of the sentence in the sentence or clause boundary. Below are the data taken of intersentential switching from the host's utterances:

As a young boy, you didn't dream about that. It wasn't in your head.

Bahkan bisa dibilang untuk pendidikan aja susah.

The data talks about the fact of the actor when he was a young boy. It explains that when he was young, he had a hard time in school to follow the subject. On the contrary, now he works together with an organization focusing on Indonesian's children who have difficulties to pursue their education. Along with the organization, he builds a program about education starting from early childhood until senior high school all over Indonesia. He wants to make sure by his privilege that he has now, he can be useful to people. Most important thing, he doesn't want children in Indonesia have the same experience like him when it comes to education.

In this data, intersentential switching appears at the beginning of the sentence. The host open the sentence begins with English and eventually finish it with Indonesian. The host switches his code at the beginning of his sentence to explain 
Fathia Anggriani Pradina - Code-Switching as Media Speech: An Evidence in Indonesian Podcast

about the thing that he wants to ask to the guest. It is clearly seen that the host wants the guest to tell his life story about his professional career he has been doing from long time ago to the present. Concerning the illocutionary acts, the intersentential switching in this data appears as assertive, because the utterance commits the speaker about the truth. Before the host throws the question to the guest, he did the research about what the guest actually wanted to be when he was a young boy. The guest's dream when he was young is not the same with his profession right now. Therefore, he seeks the truth by saying that sentence 'As a young boy, you didn't dream about that. It wasn't in your head...' before he begins to pass the next question and wants the guest to talk about it. Before he listens to the guest's answer, he says the fact first, then he will get the truth form the guest's answer. Therefore, assertive is found in the intersentential switching.

According to the data above, the intersentential switching which has assertive act regarded as the media speech in the conversation. In this data, the host using code-switching as his media speech to utter the fact of the actor's life when he was at young age. He tries to get the information from the actor. As the code-switching uses in the conversation, the host wants the actor to say clearly about the things that he has said in the previous conversation. To make the utterance more powerful and gets to the point, the host switches his code. In this case, the utterance 'As a young boy, you didn't dream about that. It wasn't in your head...' has assertive act, then lead to activity goal, which is explanation and in the final, the answer of the actor regarded as the situational code that makes situational goal achieved. In this conversation, the actor after being asked the question form the host, tells the listeners about the reason why he is doing the project. It means that, the code-switching in this utterance uses to get the situational goal in the conversation.

Jadi Ketika kita punya trauma masa lalu, melupakan itu ga baik?

Memendam juga ga baik? So how you acknowledge it?

The data talks about the topic that the content creator actively spread through her social media. By asking some expertises, together they have campaign about mental health issue. Mental health issue comes from trauma that someone's has in 
Fathia Anggriani Pradina - Code-Switching as Media Speech: An Evidence in Indonesian Podcast

the past. She said that if we forget or even keep it deep down in our heart, it will never heal. Moreover, it will affect to events that you will have in the future. Sometimes, it can affect us to deal with problem in life. The only thing that we should do with our trauma is acknowledge it, says the content creator.

In this data, intersentential switching appears. The intersentential switching occurs at the end of the sentence. The switching done from Indonesian to English. The switching done because the host wants to emphasize his question to the guest about the thing that has been discussed earlier. The sentence "So how you acknowledge it?" shows that the host tries to find the answer about something that is unclear. The data also analyze to fulfil the illocutionary acts in the switching. The illocutionary acts appear in the data is directive. If a speaker has the directive illocutionary acts in his utterance, means that the speaker asks for a particular action done by the hearer. It can be request, commands, advice or anything else. It is clear in his utterance, the host wants the guest to answer his question by giving her own experience about how to deal with trauma. In short, the answer of the guest can be concluded as advice for the listeners. So, in this data, it can be seen that the intersentential switching appears in the host's utterance is not merely a simple switching but it tends to be the directive illocutionary act.

Situational goal in this utterance can be seen from the respond of the content creator. In the conversation, it is clearly that the host uses intersentential switching that has directive. The intersentential switching with directive act leads the conversation to the activity goal. It can be said like that because after the question being thrown to the content creator, she directly answers the question. She explains the details and tries to describe the answer thoroughly. It means that the use of codeswitching in this utterance as the media speech is achieved because the situational goal is appeared.

Another data of intersentential switching is below:

Tapi lo di rumah dasteran? Enggga? Engga? Oh, gila! You don't sleep with your suit on! 
Fathia Anggriani Pradina - Code-Switching as Media Speech: An Evidence in Indonesian Podcast

The data talks about the content creator's appearance daily at home. The host curious whether she always dresses up or not because the content creator is wellknown as a person who has a good taste in fashion and becomes a trendsetter for almost all her followers. Most woman in Indonesia are usually wearing daster (woman pyjamas) at home because the cutting and the material is very breathable. That is why the host bringing up this question to the content creator. He wants to clarify whether she always dresses up at home or not. The answer says it all.

In this data, intersentential switching appears in the host's utterance. It occurs at the end of the sentence. The switching done by the host to emphasize his previous utterance, 'Oh, gila!' then, he says again in English to make the sentence clearer. Another theory that makes the switching even stronger is the expressive illocutionary act in the utterance. The sentence 'You don't sleep with your suit on' represents his expressive about the thing that he heard from the guest earlier. The guest is known as a well-dressed person, so the guest asked about what she wears daily when she stays at home. The answer was surprised the host and made him said so. As the expressive in illocutionary acts explains the speaker's attitude towards the proposition just like congratulations, excuses, thanks and any other. In this data, it shows the speaker's attitude that he was surprised knowing that the guest doesn't wear daster (woman pyjamas) at home like most common people do. In short, the intersentential switching in this data shows the host's expression about the answer. The host feels surprised.

In the utterance, the situational goal appeared from the expression. Though we cannot see their faces because is a podcast, we can see it from the words that they use. In the utterance, it is clearly seen that they both surprise from the thing that they are being discussed. Though not all situational goal appears from the sentence, it can be seen from the expression of the speakers. In this case, the words they use are showing their expression.

The second type of code switching that found from the host's utterance is intrasentential switching. The switching occurs in the middle of the sentence. usually 
Fathia Anggriani Pradina - Code-Switching as Media Speech: An Evidence in Indonesian Podcast

only insert a word, mainly lexical item to emphasize the word. The data regarding to intrasentential switching are as the following:

...yang gue salut dari elu, elu selalu ada pose baru hahahaa! Gue gak mau bilang it is new tapi ada aja.

The data talks about the pose of the content creator that she always strikes during the photoshoot. The content creator always has the ideas about the place, the outfit, the theme and also the tone of the photo that she has to do in photoshoot. the content creator is not a model. Though, as we all know, becomes a content creator means you need to always be creative. It shows clearly by the content creator here and it makes the host wondering how.

The data above classified as intrasentential switching. The switching code occurs in the middle of the utterance and the aim is to emphasize the sentence. There is 'new' as the code-switching of 'baru'. Both words have the same meaning. The host emphasizes the word in form of code-switching to show that the focus of his utterance is about her new pose (the Indonesian content creator).

Another theory attaches in the intrasentential switching in this data is assertive in illocutionary act. It classifies as assertive because the in the code-switching, the speaker commits to the truth of the expressed proposition. As mentioned before that the guest's job is a content creator. As a content creator, she demands to be always creative including in striking a pose in every photoshoot. In the data, the host talks about how the guest always has a new pose in every photo that she posted in her social media. Thus, the pose becomes trends in teenager.

As the intrasential switching with assertive act appears in this utterance, the situational goal achieved from the statement of the host. He repeats his words in two languages, Bahasa Indonesia and English (baru and new), to express things that he wants to say. In this data, the situational goal shown in code-switching not in a full sentence, but only in one word. Code-switching as media speech in this utterance is appeared as the host uses two languages to say same thing to emphasize his point in his utterance. 
Fathia Anggriani Pradina - Code-Switching as Media Speech: An Evidence in Indonesian Podcast

Another data in intrasentential switching is:

Siapa yang mungkin paling berperan di awal-awal karir lo? Nyokap your mother definitely. Lo sangat akrab dengan nyokap.

The data talks about the question about the actor's mother. The host asks whether the actor is very close with his mother and she becomes his biggest supporter throughout his career.

The data above is one of code-switching classifies as intreasentential switching which found in the interview. The host switch from Indonesian to English, 'nyokap' (a slang version to call mom) and 'mother'. The code-switching occurs in the middle of the utterance and only in a single word with the same meaning. The codeswitching occurs to emphasize the focus of the utterance.

The data also being analysed with another theory, which is directive from illocutionary act is found in the code-switching. Directive cause the hearer to take a particular action. In this case, the host makes the guest do the explanation about her mother and related with his profession now. The guest is an Indonesian male actor who is quite successful in every movie he acts. Because the question is about the guest's story at the beginning of his career. The host do not straight ask about the relationship between the guest with his mother. On the other hand, his utterance makes the guest explain about it. Only by switching a word in his utterance, the guest understands that the host wants him to explain about her mother's support along his career.

It is quite obvious to see the situational goal if the utterance has code-switching with directive act. When the opposite answer as the way we wanted to be, it can be said the situational goal is achieved in the conversation. The use of code-switching in the conversation as media speech is used really well. As we can see in the data, after the host asks his question, the actor explain about the role of his mother during his career in film industry and talks about their relationship.

The last data of intrasentential switching is:

Tapi gue seneng I'm glad lo di sini sekarang, karena there's a lot of stories to be told. 
Fathia Anggriani Pradina - Code-Switching as Media Speech: An Evidence in Indonesian Podcast

The data talks about the expression of the host because he can ma the interview happen. As he knows, the content creator has a very busy schedule and it is very hard to invite her to his show.

This data is included as intrasentential switching because the switching occurs in the middle to emphasize the utterance. The word 'seneng' is being said again as 'glad' in the utterance. The host says two words in two different languages but both have the same meaning. It somehow emphasizes what the host wants to say to the guest.

Another supportive theory that found in the data is expressive from illocutionary acts. The code-switching in the utterance classifies as expressive because it shows the host's emotion towards the proposition. In this case, the host feels unbelievably happy because of the guest's presence in the interview. The host knows that the guest is very busy. Therefore, to have her in the interview is such a happy feeling for the host. As he knows also that the guest has so much stories to share about to the listeners.

Code-switching with expressive act mostly shown by the use of two languages to say one same thing. In this utterance, the host says seneng (senang) and happy to express that he really feels overwhelmed for the presence of the content creator to do the interview. By a simple word like that, it can be said that situational goal is achieved because both of the host and the content creator share the same excitement.

The least type of code switching that occurred in the data is tag-switching. Based on the result finding in table 1, the tag switching in the data are very limited. Here are the data finding about tag-switching that occurred in the data:

\section{Lo juga tadi bilang kalu lo merencanakan untuk punya anak, right?}

The data talks about the content creator's plan. As she a newlywed, she mentions that she plans to have baby. The statement is being asked again by the host to clarify whether that plan is true or not.

The data above is one of the data that classified as tag-switching. The switching that occurs in the end of the sentence in the question form. The word 'right' in the 
utterance used to ask about the sentence that has been said previously. In this data, it shows that the host asks about the utterance that he said. Tag switching that occurs in the utterance comes as a question. It means that the host wants to make his question clear. He changes his language from Indonesian to English. If we take a look, before the tag there is no words that have the same meaning as the tag. It is clear that the tag doesn't change or even complete any words in the utterance. The tag-switching comes because the host wants to clarify the content creator's statement in the previous talk.

In line with the switching that occurs in the utterance. The tag-switching also classified as assertive. The host says so because he knows the truth, that the guest plans to have a baby, and he asks again to make sure that it is true or not. The host realize that the statement is the truth from the previous statement comes from the content creator. As she gets married, her next plan in her marriage life is to have baby. Using tag-switching with assertive function makes his statement clearer.

This data shows another assertive act in code-switching as media speech used really well. Unlike the previous data, in here the switching done in tag-switching. The situational goal can be seen because the content creator admits the utterance of the host. In other words, they share the same thoughts about the topic that they are being discussed.

\section{Kalau lo tidak menggunakan Instagram untuk apa yaa... hobby. Right! Why?}

The data talks about the fact about the use of Instagram by the actor. He says that the actor doesn't use one of the biggest social media, Instagram, to share his hobby or daily life. The actor uses the platform for his job. Do the promo for his new film, drama, collaboration projects, brand ambassador of a brand or else. The actor never shares his personal life just like how many brother or sister does he has, whether he has cat or dog or else. He does it professionally.

The data above is included as tag-switching. The host switch his code in the end of his utterance and it implies in a question form. 'Right! Why?' used as the question form to end the utterance. Tag-switching occurs to make the question clearer. It is like 
asking for clarification. There are no words before the tag-switching that has the same meaning, instead, the host uses it to ask. He changes the language from Indonesian to English. In addition, in this utterance, the host uses two kinds of tag. It is exclamation Right! And question Why? to make the actor answer his question.

The tag-switching in this data also analysed as directive illocutionary act. Directive requires the hearer to take particular action. In this case, the host wants the guest to take particular action which is explanation to answer his question. The question word ' $w h y$ ' in English is usually used to ask about reason and the question should be about the explanation of the reason. In this data, the host is asking the guest the reason why he does not use his Instagram as his hobby. In short, tagswitching and directive illocutionary act in this data make the utterance clearer about what the host tries to say in his interview.

The situational goal in this utterance is achieved because it is quite obvious to see the situational goal if the utterance has code-switching with directive act. When the opposite answer as the way we wanted to be, it can be said the situational goal is achieved in the conversation. The use of code-switching in the conversation as media speech is used really well. As we can see in the data, after the host asks his question, the actor explain about use of Instagram for him.

\section{Lo bisa berubah peran dalam waktu yang sedikit gitu and that's talent!}

The data talks about the admiration of the host to the actor skill in acting. He says that the actor can play any kind of role. He can play different role from one movie to another very easy but the result is very good. The host says that the actor gets a natural talent in this industry.

The data above is tag-switching. According to Edwards (1994), tag-switching can be both interrogatory or exclamatory. In this data, 'that's talent!' is an exclamatory. The host does not ask a question, but he says something in the exclamation form to emphasize his utterance. The host changes his code from Indonesian to English to emphasize his admiration to the actor who has such good talent in acting. As he 
knows that acting is not an easy thing to do. That is why the host saying that to the actor to respect his talent.

Related with the tag-switching that appears in the data, it is also analyzed with the illocutionary act. Expressive appears to be the illocutionary act in the host's utterance. He expresses his admiration to the guest, who is an actor that can have many different roles in each movie he plays in a short of time. He says that the actor has a real talent in acting. Both tag-switching and expressive illocutionary act in this utterance make the meaning of the switching more powerful.

In this data, code-switching with expressive act shown by the use of single language. In this utterance, the host says that's talent! to express his respect to actor for being such very good actor in film industry. By a simple word like that, it can be said that situational goal is achieved because both of the host and the content creator share the same excitement. The host says his appreciation. Unlike other data, in this data the switching done in tag-switching in exclamation form, not question. It is simply to show his appreciation.

From all the data above, it can be seen that there are several types of codeswitching and illocutionary acts appear in the conversation. Not all of the type of illocutionary acts appears in the conversation, because some of the type illocutionary acts needs a powerful position from the speaker. Nevertheless, in this study both host and guests have the same level. No one has higher level that others. The aim of the conversation is to have a good interview that will be meaningful for the listeners. Using code-switching in asking questions make the host easier to express what he wants to know to get the situational goal achieved in the conversation.

\section{CONCLUSION}

The study on code switching as media speech in Indonesian podcast has been done to find the type of code-switching along with the types of illocutionary acts to support the analysis. These two approaches were used to find the situational goal that happen from the host's utterances during the interview. The study shows that 
Fathia Anggriani Pradina - Code-Switching as Media Speech: An Evidence in Indonesian Podcast

both code-switching and illocutionary acts play a significant role in the interview and make the situational goal achieved.

The result of the study shows that there are three types of code-switching found in the data. There are intersentential switching as the most frequent switching, follow with intrasentential switching and the last is tag switching. Intersentential switching appears to be the most frequent switching in the data because the form is interview. Intrasentential and tag switching appear to make the interview run smoothly too. While for the types of illocutionary acts, assertive and directive are the most frequent. It is because in interview, the host should do the research before conducting the interview. That is why assertive appears more frequent because the host should find the truth or fact about the guest, and ask to the guest whether is it true or not. Directive finds to be frequent too because in interview, the host asks the guests to share their perspective about a topic, a reason about something and else. This makes directive appears in the data because the host wants the guests to take particular action such as sharing their experiences, giving advices to the listeners, etc.

In this study, it shows that code-switching is being used as the media speech in the conversation. The conversation conducts as the interview of two episodes in podcast. It is clearly seen that by using code-switching as the media speech, the host feels more comfortable in delivering his questions during the interview. Whether it is to ask reason, tell a story, clarifying statements or even showing his admiration or else. Everytime the host wants to emphasize his statement he always changes his language from Indonesia to English. It is not merely because he can speak English so he speaks English in the interview, but it is also because the host has something to be delivered both to the guests and also the listeners.

The study becomes interesting because the writer found that code-switching and illocutionary acts accommodate the situational goal in the interview. By using code-switching and illocutionary acts, the interview will run smoothly and will not leave ambiguousness for the guests. Code-switching and illocutionary acts supports to make the situational goal achieved in the conversation. As the result, the interview 
becomes livelier. Both host and the guest have a great time in doing the interview and make a powerful conversation for the listeners.

\section{REFERENCES}

Al-Qaysi, Noor. Al-Emran , Mostafa. (2015), Code-switching usage in social media: a case study. International Journal of Information Technology and Language Studies (IJITLS). Vol. 1, Issue. 1, (2017). pp. 25-38.

Auer, Peter. (1998). Code-switching in conversation. London and New York: Routledge

Austin, J.L. (1962). How to do things with words. Cambridge: Harvard University Press.

Bahrun, ST. Rahmaniah. Aminah, Sitti. (2020), The use of code-switching in English Foreign Language classroom of SMKN 2 Sinjai (Penggunaan alih kode pada kelas Bahasa Inggris Di SMK Negeri 2 Sinjai), Jle: Journal of Literate English Education Study Program, Vol. 01, No. 012020.

Edwards, John. (1994). Multilingualism. London: Routledge.

Fachriyah, Eva. (2017). The functions of code switching in an English language classroom. Studies in English Language and Education, 4(2), 148-156.

Hoffmann, Charlotte. (1991). An introduction to bilingualism. New York: Longman Inc.

Holmes, Janet. (2001). An introduction to sociolinguistics: second edition. England: Pearson Education Limited.

Hornberger, N. H., \& McKay, S. L. (2010). Sociolinguistics and language education. Great Britain: Short Run Press.

Idris, S. (2016). The impact of globalization, language policy, and language learning on identity construction: An ethnographic case study of a high school community in Bima, Indonesia. (Unpublishhed Dissertation). The University of Texas at San Antonio.

Kavada, Anastasia. (2015), Social media as conversation: A manifesto. Sage Journals. Doi: https://doi.org/10.1177/2056305115580793

Kristanto, J., Meilasari, P. (2018), Reasons for social media users' code switch, Advances in Social Science, Education and Humanities Research (ASSEHR), vol.188, Doi: https:// doi.org/10.2991/eltlt-18.2019.71

Lee, Sophia Yat Mei, \& Wang, Zhongqing. (2015), Emotion in code-switching texts: Corpus construction and analysis. Proceedings of the Eighth SIGHAN Workshop on Chinese Language Processing (SIGHAN-8).

Lubis, I.S., Surya, S., Muka, A.U. (2017). The use of code-switching among the late adolesecents in social media Facebook. CaLLs: Journal of Culture, Arts, 
Fathia Anggriani Pradina - Code-Switching as Media Speech: An Evidence in Indonesian Podcast

Literature, and Linguistics. Vol.3, No.2, DOI: http://dx.doi.org/10.30872/calls.v3i2.817

Maharjan et al., (2015), Developing language-tagged corpora for code-switching tweets. Proc. LAW IX at NAACL. DOI:

http:/ / dx.doi.org/10.3115/v1/W15-1608

Mave, Deepthi., Maharjan, Suraj \& Solorio, Thamar. (2018), Language identification and analysis of code-switched social media text. Proceedings of The Third Workshop on Computational Approaches to Code-Switching.

Puspawati, I. (2018). Teachers' use of code switching in EFL classroom and its functions. Journal of Foreign Languange Teaching and Learning, 3(1), 7374. https://doi.org/10.18196/ftl.3128

Rahayu, D. (2016). Bilingualism of two Indonesian siblings living in Australia. Studies in English Language and Education, 3(2), 109-121.

Retnawati, Saptina. Mujiyanto, Yan. (2015). Code switching used in conversations by an American student of the Darmasiswa program. Language Circle: Journal Lof Language And Literature X/1, 10(1), 29-35.

Rijhwani, Shruti. Sequiera, Royal. (2017), Estimating code-switching on twitter with a novel generalized word-level language detection technique. Proceedings of the 55th Annual Meeting of the Association for Computational Linguistics. Computational Linguistics. https:// doi.org/10.18653/v1/P17$\underline{1180}$

Searle, J. (1976). A classification of illocutionary acts. Language in Society, 5(1), 123. Doi: $10.1017 /$ S0047404500006837

Soliha, Imro Atus . Susandi , Ari, \& Prasetiya, Benny. (2020), EnglishIndonesian code switching applied in Pondok Pesantren Terpadu Miftahul Ulum Al-Yasini Pasuruan. Premise; Journal of English Edication and Applied Linguistics. Doi: http://dx.doi.org/10.24127/pj.v9i2.3086

Schivinski, Bruno. Dabrowski, Dariusz. (2014), The effect of social media communication on consumer perceptions of brands. Journal of Marketing Communictaions. Doi: https://doi.org/10.1080/13527266.2013.871323

Turmudi, D., \& Hajan, B. H. (2020). Education system and English Language Teaching in the Philippines: Implications for Indonesian EFL Learning. Premise: Journal of English Education and Applied Linguistics, 9 (1), 78-93. https:// doi.org/10.24127/pj.v9i1.2791

Yuliana, N., Luziana, A. R., Sarwendah, P. (2015). Code-mixing and codeswitching of Indonesian celebrities: A comparative study. Lingua Cultura. Vol.9 No.1 May 2015, 47-54, Doi: https://doi.org/10.21512/lc.v9i1.761 